Христианства, и неоценимая эстетическая ценность, привлекающая людей, как верующих, так и просто гостей своей удивительной гармонией и красотой.

\title{
Выводы:
}

Сегодня важно помнить, что церковное искусство для многих народов стало основополагающей базой для развития и становления национальных культурных традиций, ведь, помимо религиозного воспитания, церковь содействовала также и эстетическому возрастанию и просвещению народов. Она пробуждала творческие силы, одухотворяла их и направляла к созиданию уникальных памятников культуры. И в наше время, церковь, а вместе с ней и церковное искусство по-прежнему остается творческой основой, важной и необходимой для просвещения народа и побуждения его к созиданию новых памятников. Мы видим, как не только восстанавливаются монастыри и храмы, но и строятся новые. Патриарх Московский и всея Руси Кирилл официально заявил, что за 10 лет православная церковь планирует построить 30000 новых храмов [6]. Открываются иконописные мастерские [7] и школы иконописного мастерства. Создаются новые творческие коллективы, исполняющие духовную музыку, пишутся новые духовные тексты [8]. Вся эта созидательная деятельность православной церкви, пусть не напрямую, но опосредованно связана со сферой туриндустрии. Через возрождение церковных искусств, само церковное строительство сегодня формируется социо-культурное и эстетическое лицо современной России, что делает ее более привлекательной для туристов, как из-за рубежа, так и для внутреннего туристического потока.

$$
\text { *** }
$$

1. Алексий II. Доклад Святейшего Патриарха Московского и всея Руси Алексия II на Архиерейском Соборе 2000 года. [Электронный ресурc] http://www.patriarchia.ru/

2. Прокопий Кесарийский. Война с готами. О постройках. М.: Издательство Артос, 1996. 211с.

3. Трубецкой Е. - Три очерка о русской иконе. М.: Издательство Лепта-Пресс, 2003. 111 с.

4. Успенский Л.А. Богословие иконы Православной Церкви. Коломна: Издательство западноевропейского экзархата. Московский патриархат, 1994. 447 с.

5. Флоренский П. Иконостас. М.: Издательство АСТ, 2005. 187 с.

6. «Патриарх Кирилл рассказал о строительстве трех храмов в сутки» [Электронный ресурс]. https://ria.ru/20190526/1554925784.html (дата обращения 12.09.19)

7. «Иконописные мастерские в России» [Электронный ресурс]. https://www.cataloxy.ru/firms/ikonopisnye-masterskie-3743.htm (дата обраще-ния 12.09.19)

8. Нотный архив Бориса Тараканова. «Золотая Пасха» сборник песнопения Пасхальной службы. [Электронный ресурc]. http://notes.tarakanov.net/katalog/kompozitsii/pashalinaya-slyzhba_2/ (дата обращения 12.09.19)

9. Покрово-Тервенический женский

монастырь http://www.tervenichi.ru/about_mon_main_information_and_history (дата обращения 17.10.19)

10. Выступления против строительства храмов. https://www.bbc.com/russian/features-48355231 (дата обращения 17.10.19)

\section{Buryak N.Y. \\ The multicultural educational environment as a cultural phenomenon}

The Academy of marketing and social information technologies-IMSIT

(Russia, Krasnodar)

doi: $10.18411 / \mathrm{j}-02-2020-107$

idsp: ljournal-02-2020-107

\section{Аннотация}

В данной статье рассматривается ситуация, связанная с необходимостью обновления социокультурного пространства российского образования, характеризующегося его растущей автономизацией, усилением ответственности регионов за его качество. Это происходит с учетом процессов глобализации, 
интеграции в мировое образовательное пространство, растущей мобильностью человека. В связи с этими процессами в современном обществе и, соответственно, в современном образовании проявляется ситуация взаимодействия различных культур, что определяет поликультурный характер социальных процессов. Острота этой проблемы обусловлена тем, что поликультурность пространства жизнедеятельности человека стала неотъемлемой чертой современного мира.

Ключевые слова: глобализация, язык и культура, образовательное пространство, языковая личность, современное общество, культурные ценности.

\section{Abstract}

This article deals with the situation connected with the necessity to renew the sociocultural space of Russian education, characterized by its growing autonomy, increasing responsibility of regions for its quality. This is taking into account the processes of globalization, integration into the world educational space, growing human mobility. In connection with these processes in modern society and, consequently, in modern education there is a situation of interaction of different cultures, which determines the multicultural nature of social processes. The severity of this problem is due to the fact that the multiculturalism of the space of human activity has become an integral feature of the modern world.

Keywords: globalization, language and culture, educational space, linguistic personality, modern society, cultural values.

Russian education was one of the first socio-cultural determinants of social development to respond to changes in Russian society, to the problems of globalization and informatization not only as a part of the global post-industrial economy, but also as a phenomenon of special culture, which allows us to determine the moral and value basis for the creation of new mechanisms for the reproduction and transmission of cultural norms, values, knowledge, ideas, perceptions, symbols and patterns of behavior that correspond to the "challenges" of the twenty-first century.

The renewal of the socio-cultural space of Russian education is characterized by its growing autonomy of institutions and increasing responsibility of regions for the quality of education. This is taking into account the processes of globalization, integration into the world educational space, and growing human mobility. In connection with these processes in modern society and, accordingly, in modern education, the situation of meeting and interaction of different cultures is clearly manifested, which determines the multicultural nature of social processes. The acuteness of this problem is due to the fact that multiculturalism of the human life has become an integral feature of the modern world, the Russian Federation and its regions.

This problem concerns not only the education system of Russia and its regions, but also the educational practice of the entire world community, which indicates the relevance, scale and significance of this problem for modern civilization. It is fully manifested in higher education and touches upon the issue of systemic changes in the professional training of future specialists in the field of higher professional education and determines the need to form in federal and regional universities of the Russian Federation the readiness of graduates to live and work in an open, democratic post-industrial society, where representatives of different races, nations and nationalities coexist and interact, and, therefore, those who speak different languages, religions, traditions, that is, different cultures [1].

At the same time, the living conditions of nations and nationalities, their mentality, behavioral stereotypes, lifestyle, traditions, language, bilingualism and other manifestations of cultural norms and values are very important. At the present stage of development, the system of higher professional education should ensure the readiness of a specialist to carry out professional activities in the global society and, at the same time, ready to take into account 
the specifics of all-Russian culture and national cultures, which determine the specifics of solving professional tasks.

With the development of cultural and economic ties between countries and peoples, the role of learning foreign languages is growing. Every year, there is an increasing demand for specialists who speak foreign languages. At present, one of the most important directions of education development is the use of a competence-based approach, in particular, the development of skills and abilities related to the practical application of human communicative abilities, cultural, social and informational competences. Despite the fact that this issue is widely discussed in the scientific and pedagogical literature, the cognitive approach prevails in higher education institutions, and students are forced to remember (for the time being) a significant amount of information instead of developing basic competencies necessary for successful work.

Specialists note the insufficient level of foreign language skills of university graduates, and those who even have good knowledge are not always able to apply them effectively in the field of domestic and professional communication. Added to this is the lack of knowledge of the linguistic and cultural meanings of other languages, traditions and modern features of development of different peoples. In this regard, there is a need to educate students who are able to act as subjects of the dialogue of cultures. One can say that a foreign language carries not only a system of linguistic knowledge, but also a system of knowledge about social norms, spiritual values, and a set of relations between people [3].

Mankind is now moving towards cultural pluralism, dialogue, polylogue and the search for a harmonious balance between cultures. Integration into the pan-European educational space in the field of studying the linguistic personality should take into account cultural differences, including in the methods of teaching foreign languages. Modern education implies, first of all, the development of students' personality and cognitive abilities, the formation of an integral system of universal knowledge, and not only mastering the sum of knowledge in certain academic subjects.

Obtaining quality education in higher education should take into account national interests and global development trends. The aim is not only to train a highly professional specialist in a particular field, but also a "person of culture" capable and ready to communicate and cooperate with people of different nationalities, races, religions and cultures, peaceful and fruitful coexistence in modern society. It is only through dialogue with another culture that a certain level of self-consciousness can be achieved, since in the dialogue between the two cultures, each one maintains its own unity and open integrity, while enriching the other. In the twenty-first century, it is becoming increasingly clear that humanity is evolving towards a more interconnected and interdependent world.

In the conditions of market economy and fierce competition a number of strict requirements are imposed on the modern specialist: in addition to professional knowledge, skills and abilities it is necessary to master a personal computer, foreign languages, as well as linguistic and ethical norms of the state language and methods of successful communication. Speech is a kind of "dress", which meets a potential employee, business partner, manager. However, the current state of the language and the level of development of the language culture of different strata of Russian society cause serious concern to scientists. There is a clear need to improve the culture of linguistic personality at all levels of education. Today, there is an urgent need for curricula, textbooks and teaching aids, as well as reliable pedagogical technologies to raise the level of culture of the linguistic personality. This problem becomes even more acute and urgent in the conditions of official bilingualism.

An important goal of teaching students a foreign language is to develop a personality who is willing and able to enter into intercultural communication, professionals who are able to acquire self-education. Participation in a variety of international programs, the opportunity to study and work abroad implies not only a high level of foreign language skills, but also 
such qualities as communication skills, lack of language barriers, knowledge of international etiquette.

The linguistic personality is complex in its manifestations and depends on many factors, the most important of which, in our opinion, is the personal factor in speech communication, as individuality is manifested in unity with the conditions of social and cultural environment and, as a rule, has its own language image, speech culture and evaluation of speech works, both orally and in writing.

The quality of foreign language teaching is largely determined by the differentiation and individualization of teaching. The most universal means of communication is language, and the study of its socio-cultural dimension is one of the most important and fruitful areas of research. Sociality of a language should be understood as a dialectical unity of language and culture, language and society. The task of connecting people into a single community is expressed in a number of social functions of culture, in particular, in information and communication and sign language. Consequently, the importance of understanding of the sign function of culture by all subjects of education is growing. It is impossible to master the achievements of culture without studying and knowing the corresponding symbolic systems. Thus, language, understood as a means of thinking and communication, as well as a symbol, is an essential means of mastering, developing and maintaining culture. The cultural approach to the content of the concept of the culture of the linguistic personality, as opposed to the philological one, is also relevant because it provides an opportunity to predict the linguistic appearance of the individual and society as a whole on the basis of historical precedents and to determine the importance of those cultural values that underlie speech communication activities. In this connection, the development of a model for the formation of a culture of linguistic personality in the multicultural environment of the university is very relevant [2].

The reference to the interrelation of culture and language indicates an important methodological shift in the science of language, the transition to the study of language in close connection with the individual, his thinking and practical activities and, as a result, to the study of the culture of linguistic personality. At present, the multicultural educational environment is considered as a cultural phenomenon, a mechanism of social experience transfer, a sphere of pedagogical values, a part of the pedagogical culture of the teacher, a new information environment, the paradigm of education of the XXI century.

$$
* * *
$$

1. Buryak N.Yu. Kultura yazyikovoy lichnosti v polikulturnoy srede VUZa. Diss.. na soisk. stepeni k. kulturologii. KGUKI.- Krasnodar,2012.-S.100-157, 291p.

2. Gumboldt fon V. Yazyik i filosofiya kulturyi / V. fon Gumboldt. - M., 1985.

3. Pavelko N.N. Kultura kak integriruyuschiy faktor $\mathrm{v}$ obrazovatelnom protsesse vyisshey shkolyi: monografiya. - Krasnodar, 2006. - 396p. 